Original scientific article

UDC: 614.2:616.89-056.24(469)"19/20"

DOI: $10.25106 / \mathrm{ahm} .2017 .0412$

\author{
Teresa Nunes \\ School of Arts of Humanities, ULisboa \\ Institute for Contemporary History, UNL \\ Lisbon, Portugal \\ E-mail: teresa.nunes@campus.ul.pt
}

\title{
REPUBLICANISM, POLITICAL CHANGES AND MENTAL ILLNESS IN PORTUGAL (1889-1926)
}

\begin{abstract}
For the last decades, Portuguese historiography has been well aware of republican movement and, subsequently, party, founded in 1876, analysing its complexities, ideological heterogeneity, political options and the nature of public intervention until 1910, being this a year decisive moment of institutional rupture in Portugal, by the rise of republican regime.Although the continuous efforts, some topics on Portuguese republicanism and Republican Regime remain not fully understood in a comprehensive manner, relevant in order to achieve a broader framework to Portuguese political ideas and opposition's nature or practice to monarchical liberal system. One of these aspects is the construction of republican discourse on public health and, more particularly, on issues of mental sanity since July $4^{\text {th }} 1889$, year of mental illness bill, up to 1910 . The present paper intends to give some contributions on the matters previously appointed. Structured in three parts, the text aims to provide a characterization of Portuguese situation on mental illness during the second half of $19^{\text {th }}$ century. Based on institutional sources - government' journals, diaries of legislative chambers, hospitals balances and documents from kingdom' ministry - scientific reports and press, the first part introduces a global frame regarding data for people affected, specialized facilities, the insertion of psychiatric illness on general hospitals, the relation between mental diseases and charity institutions, most frequent treatments and financial resources associated. The second part relies on the analysis of republican propaganda and interventions on mental diseases, in order to understand the role and relevance played in the images built by Republic Party on Portuguese monarchical' institutions. Special emphasis should be given to the works produced by eminent republicans, with degree in medicine, António José de Almeida (1866-1929), and others, specialized on mental diseases like Miguel Bombarda (1851-1910) or Egas Moniz (1874-1955), by a systematic use of scientific arguments to criticized the Portuguese political structures, considered as the result of straight relation with Catholic Church. On the other hand,
\end{abstract}


the same kind of scientific arguments would be applied to underline the structural incapacities intrinsic to royal families and, for extension, the harmful associated to monarchist administration (Antão de Melo, A Imbecilidade e Degenerescencia das Famílias Reais, Lisboa, 1908). The third part is devoted to transformations projected on new institutional environment and those effectively executed on mental illness assistance after the proclamation of Portuguese Republic. Particular attention should be provided to bill approved on this issue in $11^{\text {th }}$ April 1911, to underline main republican options, observing its implementation and limitations. The analysis ought to be also focused on controversial relations between laicist Republic and religious congregations, expelled out of the country in October 1910; the one of the exceptions being the order of Saint John of God, devoted to mental diseases patients.

Keywords: Portugal

Non MeSH: mental illness, Republicanism, mental health reforms

\section{Portugal and mental illness during the $19^{\text {th }}$ century}

In 1884, António Maria de Senna published the results of an extensive research, developed for some years, produced upon Portuguese abilities to response on mental diseases, psychiatric public policies and scientific interest regarding this subject [1]. ${ }^{1}$ Professor at Medicine School, University of Coimbra, but also the dean of Hospital of Count of Ferreira and member of the House of Lords between 1879 and 1888, António Maria de Senna (1845-1890) was regarded as one of the very few Portuguese physicians known by his academic work and professional experience in mental illness diseases. Simultaneously, Senna was recognised as representative of Philippe Pinel and Jean Étienne Dominique Esquirol's medical trends to deliver comfort and new social perspectives to psychiatric patients [2-5].

With this work, Senna succeeded to bring Portuguese public opinion and, consequently, to open debate the scenarios involving the general conditions devoted to this particular illness, granting a special emphasis to diagnostic methods, therapeutics and social insertion. By the mid 1880s, Portuguese state revealed a complete lack of interest in each one of these items, which would drive the author to classified Portuguese answers, public or private institutions, as preservation of medieval ages.

Although public concerns with psychiatric diseases inspired the decision of creating special nurseries in Portuguese central hospital, São José in Lisbon, since 1818 - São Teotónio and Santa Joana, for male and female patients - this option turned to be more consistent with safety measures and less with treatment issues. Nevertheless, even for this purpose, the two facilities were evidently most insufficient to receive all patients, especially the indigents, which constituted a reality not fully known by Portuguese authorities.

1 Other books published by the author on the subject: Delírio nas molétias agudas. Coimbra: Press of the University; 1876; Discursos sobre o sistema penitenciário proferidos na Câmara dos Pares nas sessões de 5 e 7 de Maio de 1888. São Paulo: Teixeira e Irmãos; 1889; Os Atestados médicos para admissão de doentes nos hospitais de alienados. Lisbon: Typ. Elzeviriana; 1883. 
In fact, during the first half of $19^{\text {th }}$ century, the identification of mental illness was a difficult problem in Portugal, since the School of Medicine didn't offer any specific preparation to future doctors in this scientific field. On the other hand, between 1818 and 1848 , the patients in hospital were usually followed by recently graduated personnel, without any professional experience to overcome the poor academic formation. To Senna, the explanations to these institutional options were a direct consequence of an ancient perspective on mental illness, strangely preserved in Portugal as a sign of national decadency.

Assuming the $16^{\text {th }}$ century Reformation as a key moment on the understanding for psychiatry and the mental patients, Senna emphasised how the Catholic legacy persisted in the Portuguese liberal system, observing a huge difference between the political ideas and discourses addressed by the news institutions and medical practice. Defending a full modernization of the system, the author conceded great importance to the reforms of mental premises regarding medical class which would be achieved by a drastic rupture of academic patterns. At the same time, the author didn't value the mid century reforms, mainly the institution of a hospital devoted exclusively to mental diseases. The Hospital of Rilhafoles was created after an inquiry to living conditions and treatment methods used in Portugal. In fact, this document exposed the inhuman and the uncivilized manners by which patients were treated and, not less relevance, a framework known beyond Portuguese borders, as a result of Marchand's visit to Portugal, in 1844 [6].

The French physician drew a dark sketch regarding Portuguese environment to mental health treatment, an image with heavy consequences in political system awareness on the subject. Although the Portuguese executive had taken measures as the decree of $23^{\text {rd }}$ July 1842 , in order to provide mental patients a proper therapeutic in facilities built specifically to this effect, according to European patterns, mostly French and English, the feedback to Marchand's ideas and the inquiry hold afterwards to confirm the visitor's perceptions on national nurseries at São Josés Hospital, forced Portuguese authorities to formulate a solution.

The new public policies were announced on $14^{\text {th }}$ November 1848; recognizing the incapacity of current structures to offer the necessary attention to psychiatric ill persons and attending to previous medical reports presented by the physicians responsible by the two nurseries, mainly Clemente Joaquim d'Abranches Bizarro and Caetano Beirão's works, the executive decided to destine a vacant building, former monastery, to psychiatric patients. Far from the ideal solution, conceived by Bizarro's 1835 report, following to the studies published in the Journal of Medical Science Society, this facility wouldn't match the requirements associated to modern conceptions as the English example, quite inspiring to this author.

The Portuguese monarchical regime took another direction, far more pragmatic and less concerned with well being of mental health patients. In fact, the basis for the decision is consistent with the necessity of reducing pressure on Central Hospital, São José, which would continue to be responsible for the scientific and financial 
managing of the new space - an aspect also present in Bizarro's analysis as one of the key problems of the Portuguese assistance system.

The patients transfer begun in late 1848, according to new dean's guidance, Francisco Pulido Valente, and was concluded by January 1850, with the settlement of male ill persons. Although maintaining the old attachments to central hospital, Valente proved to be well succeeded as internal regulations were concerned, establishing separate areas to different diagnoses and behaviours. Nevertheless, the structural problems associated to psychiatric treatment remained untouched. Soon, the new facility was overcrowded, a reality that turned impossible to innovate in therapeutic terms. On the other hand, the financial dependence from Central Hospital constituted a huge difficulty to Rilhafoles's administration, often arguing for the need to more economic support. At last, no new human resources were granted to the hospital which had no means to avoid further patients, since no regulations to admit mentally ill persons were made or approved by Portuguese Governments since the hospital's opening.

On $29^{\text {th }}$ September 1864 , some legislative changes came to give a new status to Rilhafoles: the hospital would receive all psychiatric patients, especially the violent ones, the admissions should be accomplished with a diagnostic's description and also a report for violent acts committed by the ill person, just like a broader identification, extensive to patient's family.

Two years after, a new inquiry was hold, which justified the appointment of a new board: the dean, Guilherme da Silva Abranches, favoured a treatment perspective built on a strong contribution of clerical component. In consequence, Rilhafoles came to integrate a religious staff - mainly congregations' members - to assist daily and participate in an active manner in medical practices. Based in C. Roller's ideas about psychiatric approach [7], this model emphasised the virtues of a moral treatment, as important or more than the use of chemical substances, hydrotherapies, social contacts, especially with family members, the outdoor experiences, particularly in natural environments and the involvement in agricultural tasks.

Institutionally, Abranches's options didn't received a consensual public or political acceptance, a reaction explained by the key purposes of Portuguese liberal system, from 1832, and not fully achieved in the second half of $19^{\text {th }}$ century - an unquestionable separation between Portuguese State, it's functions and religious agents, especially Catholic Church. The relevance granted to religious elements, in assistance, meant recognizing liberal incapacity of dealing with health issues and conceiving a new structure, indisputably public.

Scientifically, Abranches's approach was also controversial for academic and medical communities. Roller's understandings were quite questioned for inserting and valuing moral categories as part of mental illness. Especially in Portuguese case, a reality in which the causes for mental degeneration were often related by specialists with negative Catholic Church's influence in society. Perceptions of hell, images of devil, terrifying fears inspired by an angry divine entity could play an important role 
in weak mind's instability. As Senna stated in his book, "a village provided with a good school and a moderate priest, not accurate in preaching the horrors of hell and awful persecutions of the devil, but prays the word of the Lord by his honest conduct and hard work, that's enough to secure the psychic conditions of inhabitants, especially the less protected by biological factors" [1 p100].

These critics haven't made any substantial institutional change; the system would persist until $24^{\text {th }}$ March 1883, an important date as meant the opening of a new psychiatric hospital in Porto, built observing modern hygienic conditions and patients' necessities. This facility, Hospital of Count of Ferreira, financed by a private legacy, constituted a rule model to psychiatric assistance in Portugal, most appreciated in Lisbon where Rilhafoles missed its function of treating mental illness being, simultaneously, known by the huge mortality caused by epidemics, some of them avoidable.

On the other hand, the prevention issues and methods were absence from public concerns although the number of patients seemed to grow during the second half of $19^{\text {th }}$ century. Even if the general inquiries to demography provided insufficient information, few doubts remained for medical community regarding the enlargement trend of psychiatric diseases in Portugal.

For the 1878 general demographic inquiry, Portuguese reality was the following [8]:

\begin{tabular}{|l|c|c|c|c|c|}
\hline \multirow{2}{*}{ Districts } & Male & Female & Males & Female & \multirow{2}{*}{ total } \\
\cline { 2 - 5 } & Birth & Birth & achieved & achieved & \\
\hline Viseu & 34 & 21 & 146 & 144 & 345 \\
\hline Guarda & 28 & 10 & 85 & 87 & 210 \\
\hline Bragança & 31 & 22 & 44 & 40 & 137 \\
\hline Braga & 52 & 35 & 58 & 86 & 231 \\
\hline Vila Real & 34 & 30 & 55 & 43 & 162 \\
\hline Castelo Branco & 23 & 14 & 36 & 52 & 125 \\
\hline Viana do Castelo & 15 & 13 & 50 & 59 & 137 \\
\hline Aveiro & 29 & 23 & 53 & 58 & 163 \\
\hline Porto & 34 & 37 & 93 & 128 & 292 \\
\hline Coimbra & 44 & 31 & 55 & 54 & 184 \\
\hline Leiria & 26 & 25 & 37 & 32 & 120 \\
\hline Santarém & 29 & 21 & 32 & 35 & 117 \\
\hline Portalegre & 7 & 13 & 17 & 14 & 51 \\
\hline Beja & 13 & 6 & 25 & 21 & 65 \\
\hline Faro & 14 & 2 & 33 & 32 & 81 \\
\hline Évora & 4 & 8 & 10 & 15 & 37 \\
\hline Lisbon & 20 & 20 & 57 & 22 & 169 \\
\hline Continent & 437 & 331 & 886 & 972 & 2626 \\
\hline
\end{tabular}


In 1882, district statistics draw a harsh scenario on mental diseases evolution, not entirely accepted by medical community and, consequently, urged to correct the official data by constructing a probable total for each district through the consultation of local physicians, appealing to their experience and knowledge [1 p105]:

\begin{tabular}{|l|c|c|c|c|}
\hline \multicolumn{1}{|c|}{ District } & Male & Female & Total & Probable Totals \\
\hline Porto & 177 & 109 & 276 & 670 \\
\hline Vila Real & 110 & 92 & 202 & 323 \\
\hline Braga & 73 & 51 & 124 & 388 \\
\hline Bragança & 9 & 1 & 10 & 162 \\
\hline Viseu & 82 & 58 & 140 & 291 \\
\hline Faro & 26 & 16 & 42 & 167 \\
\hline Leiria & 51 & 26 & 79 & 316 \\
\hline Beja & 3 & 4 & 7 & 213 \\
\hline Guarda & 17 & 3 & 20 & 326 \\
\hline Castelo Branco & 13 & 15 & 28 & 192 \\
\hline Évora & 42 & 12 & 60 & 161 \\
\hline Aveiro & 79 & 48 & 127 & 315 \\
\hline Coimbra & 101 & 58 & 159 & 381 \\
\hline Santarém & 49 & 47 & 96 & 460 \\
\hline Portalegre & 34 & 11 & 45 & 134 \\
\hline Lisboa & 29 & 13 & 42 & 1282 \\
\hline Total & & & & 5999 \\
\hline
\end{tabular}

At the end of $19^{\text {th }}$ century, official data registered an increasing growth of mental diseases in Portugal, as stated in 1890 Census [9]:

\begin{tabular}{|l|c|c|c|c|c|}
\hline \multirow{2}{*}{ Total } & Male & Female & Male & Female \\
\cline { 3 - 6 } & & By Birth & By birth & Achieved & Achieved \\
\hline Continent & 2684 & 614 & 511 & 877 & 682 \\
\hline Aveiro & 97 & 31 & 20 & 27 & 19 \\
\hline Beja & 20 & 7 & 5 & 2 & 6 \\
\hline Braga & 151 & 45 & 39 & 33 & 34 \\
\hline Bragança & 95 & 40 & 43 & 5 & 7 \\
\hline Castelo Branco & 108 & 52 & 51 & 4 & 1 \\
\hline Coimbra & 150 & 81 & 37 & 7 & 5 \\
\hline Évora & 25 & 9 & 12 & 3 & 1 \\
\hline Faro & 47 & 11 & 14 & 12 & 10 \\
\hline Guarda & 177 & 46 & 51 & 46 & 40 \\
\hline Leiria & 48 & 12 & 12 & 9 & 15 \\
\hline
\end{tabular}




\begin{tabular}{|l|c|c|c|c|c|}
\hline & Total & Male & Female & Male & Female \\
\cline { 3 - 6 } & & By Birth & By birth & Achieved & Achieved \\
\hline Lisboa & 795 & 22 & 7 & 479 & 287 \\
\hline Portalegre & 87 & 8 & - & 15 & 14 \\
\hline Porto & 581 & 135 & 113 & 169 & 164 \\
\hline Santarém & 37 & 8 & - & 15 & 14 \\
\hline $\begin{array}{l}\text { Viana do } \\
\text { Castelo }\end{array}$ & 65 & 24 & 15 & 11 & 15 \\
\hline Vila Real & 109 & 17 & 27 & 26 & 39 \\
\hline Viseu & 121 & 55 & 56 & 4 & 6 \\
\hline
\end{tabular}

The efforts presented by António Maria de Senna in parliament were rewarded by the approval of a funding bill, exclusively destined to support the Portuguesa psychiatric facilities, on $23^{\text {rd }}$ May 1885 . The revenues were constituted by a percentage upon passport licences, half of annual value of properties formerly belonging to Catholic convents or monasteries extinguished in 1834, and nobility titles, among others, which would be insert in annual public budget. This bill, clearly inspired by Bizarro's work and requirements about independent funding to psychiatric treatment and patients would resuscitate a polemic issue regarding Rilhafoles's organization namely, its dependence to Lisbon Central Hospital, São José.

By 1889, Portuguese government reacted by announcing the first general law on psychiatric assistance system: approved on $4^{\text {th }} \mathrm{July,} \mathrm{this} \mathrm{legislative} \mathrm{initiative} \mathrm{created}$ a structure divided in four regions - the first, covering the north: Viana do Castelo, Braga, Bragança, Vila Real, Porto e Aveiro; the second, respecting country's central part: Coimbra, Viseu, Guarda, Castelo Branco e Leiria; the third, still regarding part of the central and focused in south and Madeira islands: Santarém, Portalegre, Lisboa, Évora, Beja, Faro e Funchal; at last, the fourth, including Azores Islands, Horta, Ponta Delgada e Angra do Heroismo [10].

According to this law, Portuguese executive was authorized to build and equip a hospital for each region, with different characteristics: a new facility in Lisbon was envisaged to receive 600 patients, of both sexes, with special conditions to psychiatrics teaching and two nurseries, reserved to mental ill persons convicted by judicial courts. Still in the capital, Rilhafoles ought to be transformed into an asylum, prepared to receive 300 patients. For Coimbra and S. Miguel, the same model would be implemented, taking into account the demand and demographic structures, traduced in a facility for 300 patients in the first case and 200 for the second. Regarding Porto, the law predicted two key changes as the Hospital of Count of Ferreira would be integrated in the public assistance system, being complemented by an asylum, projected for 200 patients. No less important, this initiative ordered the construction of facilities attached to penitentiaries to offer special treatment to convicted criminals with recognized psychiatric symptoms. 
This plan would not be accomplished; instead, in 1898, Rilhafoles was officially considered as the psychiatric hospital in Lisbon, although no structural reform had been made. Growing difficulties in Madeira, by the absence of new facilities in the capital, inspired Madeira's parliament member to request an old monastery to install a psychiatric institution to attend the island's needs, in 1902. On the other, in 1893, the religious order Saint John of God, specialized in psychiatric assistance, submitted a proposal to found an asylum in Portugal, which was accepted permitting a diversification of agents involved. Before the end of the century, Sacred Heart of Jesus, a female religious order also associated with the previous, was admitted in Portugal to treat female patients.

Thus, as Progressist member Adriano Anthero described in parliament, on May 1908, in psychiatric terms, national reality could be characterized as chaotic and extremely insufficient. According the calculations elaborated by medical community, Portugal would have no less than 12.000 patients but the ability to deal properly with ill persons were restricted to Rilhafoles, with a capacity of 758 people, Count of Ferreira Hospital, receiving 520, the asylum of Saint John of God, in Telhal, prepared for 84 patients, the asylum of Sacred Heart of Jesus Sisters, in Idanha, with 150 female patients, and, at last, the psychiatric Hospital of Câmara Pestana, in Madeira, treating 22 patients [11].

\section{Portuguese Republican party, mental illness and political propaganda}

Officially founded in 1876, the Portuguese Republican Party achieved gradually an evident public support in urban areas, especially the most populated during the following decade. With undisputable roots in Lisbon, soon the Party extended its network to Porto and Coimbra, through students, teachers, militaries, merchants and liberal professionals' mobilization against the monarchical system, based on key issues for Portuguese sovereignty. Not strangely, diplomatic relations and, most of all, the connexion between Portugal and Great Britain assumed particular importance to republican political propaganda.

Simultaneously, the economic and social model implemented by monarchic' executive during the second half of $19^{\text {th }}$ century raised some crucial subjects, extremely explored by republican political action. As Portuguese historiography has studied, Portuguese Republican Party, following French Republicanism, elected key themes for its activity and members' recruitment: political reforms in electoral, fiscal, military and labour sectors, redefinition of State's functions and its relation with Portuguese society which, consequently, would mean promoting secularism regarding all public spaces and structures $[12,13]$.

For Portuguese republicanism, Catholic Church stood as an adversary in both ideological and institutional terms. Being a strong support to absolutism, until 1820, Catholic Church has shown the ability to survive and adapt to the liberal order in which came to assume an important and undoubtedly role in sensitive areas as edu- 
cation or health assistance. At the same time, Catholic Church maintained a strong presence and influence in Portuguese society, namely in rural areas known by conservative convictions and fewer those willing to accept the political changes, less the ruptures.

Subscribing the unaccomplished liberal reforms conceived during the first half of the $19^{\text {th }}$ century, especially Mousinho da Silveira or Passos Manuel's ideas, Portuguese republicanism defended an effective modernization in economic and social senses, through reforms which, as clearly stated, were incompatible with monarchical system. Assuming a gradualist conception during the 1870s and the 1880s, the Republican Party would react to monarchical' reinforced measures regarding electoral law or administrative organization, responsible for cutting republican's ability to grow politically as part of the institutional environment. In the last decade of the $19^{\text {th }}$ century, Republican Party converted to the benefits of the revolutionary rupture, even if the 1891 attempt to install a republic in Portugal failed. Nevertheless, the revolution seemed to be the only alternative to reach power and by 1897 , one of republican's internal debates was focused on how to achieve a revolutionary action and which political priorities should be adopted by the republican institutions.

In this political context, mental illness played an evident part, quite complex, since the theme provided republican with arguments to criticize monarchical institutions' options and functioning, as a regime, but also to present the crown and its representatives - direct and indirect - as elements of an archaist system, not compatible with modernity and enable to address measures needed for national progress and sovereign interests in Europe and abroad.

For the first aspect, the successive interventions of Miguel Bombarda and António José de Almeida were, in different moments and contexts, of utmost relevance. Rilhafoles's dean in 1892, Bombarda took a leading role in exposing psychiatric assistance deficiency in Portugal since 1891 [14]. Appointed to join a commission to study how 1889 resolutions ought to be implemented, Bombarda gained prominence by the assertive critics to state's indifference to a large number of patients which wouldn't find treatment or any medical follow-up even if all hospitals and asylums were built [15]. In the next years, Bombarba's activity grew in the Portuguese scientific press, mainly in Medicina Contemporânea, publishing the annual reports regarding Rilhafoles's data, usually accompanied by heavy critics to financial dependence from São José Central Hospital.

In June-July 1894, Bombarda presented an ambitious plan to renew Rilhafoles, based on a key premise, the entire independence from other health institutions, followed by a comprehensive application of funding devoted by 1885 law to psychiatric assistance. Bombarba's objectives were fully explained in Medicina Contemporânea: enlarging the use of hydrotherapic methods, embracing news chemical therapies, extending labour houses and agricultural area associated to Rilhafoles. Thus, Bombarda's project was consistent with the state's attribution of new spaces in order to 
install teaching facilities, mortuary, a pharmacy, laboratories and accommodation to medical staff, desirably reinforced [16].

Inspired by Senna's conceptions regarding psychiatric disease and its causes, Bombarda emphasised most especially the relations between poverty, excessive religious influence and mental degeneration process. In this sense, the author established a clear correlation between political incapacity to develop social progress and mental illness growth in Portugal. By extent, public lack of concern with psychiatric patients assumed new proportions since incompetence soon would be described as an uncivilized and inhuman form to attend to most primarily social needs. This image would be frequent in Bombarda's works after visiting psychiatric nurseries in Madeira, during a tour in 1898. As stated, "there's a thing called civilization which has its requirements, there's a thing called humanity which has its impositions" [17]. Portuguese monarchical state followed none.

Meanwhile, this same image echoed in republican newspapers. Defined as a last trace of Portuguese inquisition, the psychiatric assistance were characterized as an entity devoted exclusively to incarceration of those considered, by not very reliable diagnosis, mentally ill persons. Moreover, the awful conditions offered to the unfortunates submitted to this infernal structure would certainly lead to madness [18].

Once elected to Portuguese parliament, Miguel Bombarda insisted in criticizing monarchic political system for neglecting psychiatric patients and, at the same time, ignoring the legislative initiatives promoted in their behalf. Overcoming this situation meant, to Bombarda, the presentation of a comprehensive project, involving the different aspects considered essential to safeguard ill persons and promote a full recovery. The project was announced in Portuguese chamber in $20^{\text {th }}$ April 1909 and conceived multiple treatments according to patient's conditions and needs, either in hospitals or in family communities, especially selected to this effect. Bombarda's system relayed on a special committee - committee for protection of psychiatric ill person - formed by both medical and law staff, competent to secure patients' rights and necessities in legal issues as in assistance topics [19].

This initiative, unanimously considered in Portuguese academic sectors, contributed to foster a straight correlation between medical schools in Lisbon, in Porto and Medicine Faculty in Coimbra, with the social engagement proposed by Portuguese republicanism. By June 1910, Bombarda's project was still waiting to be discussed in chamber, reason for Egas Moniz' intervention, in his own behalf as according to Faculty of Medicine interests, in order to speed the proceedings required to allow a decision on this matter [20].

Other republicans took effective part in this political debate in Portuguese parliament during the constitutional monarchy. António José de Almeida, schooled in Medicine by University of Coimbra and leading figure to Portuguese Republican Party in late $1890 \mathrm{~s}$ and the beginning of $20^{\text {th }}$ century, achieved high relevance by discussing public health system, in Portugal as in Portuguese colonies [21]. More precisely, Almeida has shown particular attention to the causes of psychiatric disease, 
explained by physiologic' factors. Simultaneously, by poverty traduced in poor living and working conditions, alcoholism, criminality and endangered behaviours which would culminate in a new cycle of misery, associated with Portuguese penitentiary system.

To Almeida, after achieved psychiatric diagnosis, patients' recovery was seriously compromised by the environments at asylums or hospitals, the straight proximity to other ill persons and the lack of medical assistance. As described by Almeida, the methods used to hospitalization of these patients were undignified, contributing to a most certain erosion of psychiatric abilities even in cases of temporary disorders. These ideas and critics were presented in 1907 and again in 1908 [22-24].

From an institutional point of view, psychiatric disease and its determinant factors, originated by consanguinity, assumed a prominent position on republican arguments to address monarchic' insufficiencies. A year after Carlos I death, during the long and highly disputed public debate regarding his successor's abilities to act according to royal responsibilities, Antão de Mello published a controversial work about royal families' decadency [25]. ${ }^{2}$

Defining degeneration as diminished resistances, both psychological and physi$\mathrm{cal}$, the author drew a direct parallel between Europe's political trends and monarchic regimes, its general characteristics as its foreign and internal consequences. Looking up to Esquirol's works, Mello tried to demonstrate assertively how European royal families were more likely close to different forms of dementia, providing Russian tzar Nicholas II as a comprehensive example, based on Foster Frazer's understanding of Russian Empire. Surely less violent, Portuguese royal family was no exception in Mello's framework to whom, according to Júlio Dantas's analysis on Portuguese royal heredity, national political regime couldn't be anything else than an archaism and the first active factor contributing to Portugal's catastrophe, measured on European powers disputes on Portuguese colonies or on economic, financial and social crisis experienced in Portugal since the last two decades of $19^{\text {th }}$ century.

In conclusion, Antão de Mello considered monarchic system as an assault on people's rights and a crucial element to explain the gradual erosion felt by European powers in different geopolitical scenarios as Latin America or Asia. As concerning Portuguese reality, Bragança’s dynasty represented the key reasons to national decadency since the $17^{\text {th }}$ century and its prevalence would drive both nation and empire to its extinction.

\section{Portuguese Republic and mental illness assistance}

Planned for long time, Portuguese republican revolution, on $5^{\text {th }}$ October 1910, came to be strongly tied with Miguel Bombarda whose death, two days before the revolutionary events, functioned as the ultimate turning point to republican initiative of attacking monarchic' institutions. Being an national hero and one of revolution's

2 About Antão de Mello: Baptista J. O Cinco de Outubro. Lisbon: Arcádia; 1964. 
martyrs, Miguel Bombarda's work inspired new authorities on subjects related to general assistance, medical teaching and regulations on national psychiatric system, its agents and functions.

Almeida, as ministry of Interior, was responsible for these reforms, mainly decided during the first semester of 1911. Acting according to a new state's conception, public authorities were called to look closely to causes of mental diseases, considered in a broad range, in order to achieve a well succeed prevention. These premises are evidently identified in law of $25^{\text {th }}$ May 1911 , about public assistance organization, a text where pauperism, materially and morally speaking, was marked as primary internal adversary of Portuguese State. The efforts involved in "war on poverty" consisted in a more than 5.000.000 reis annual investment, divided between different entities, applied to identity indigents in great cities, especially in Lisbon, and provide these individuals the conditions and abilities to overcome their misfortune.

Medical teaching reform, approved by Provisional Government decree on $22^{\text {nd }}$ February 1911, also associated to Interior Ministry, elevated psychiatry as a medical speciality, present in all Portuguese medical faculties - Coimbra, as before republican revolution, and in Lisbon and Porto, cities where the creation of new Universities transformed the previous medical schools into faculties.

Not least important, the Republican Government has legislated on Psychiatric Assistance on $11^{\text {th }}$ May 1911, an initiative of Interior Ministry, largely traducing the principles hold on Bombarda's law project in 1909.

Rilhafoles Hospital, renamed Miguel Bombarda, maintained its centrality regarding psychiatric treatment, being complemented by new facilities which would be built in the country in a short period. This function justified its independence from Lisbon's Central Hospital, benefiting from autonomy in financial, scientific and administrative terms. Further regulations were presented on $18^{\text {th }}$ August 1911, to consolidate government's intentions to psychiatric assistance and research, a field fully delivered to Miguel Bombarda's hospital activities in the capital.

The immediate impact of executive's decisions on Portuguese psychiatric institutions was measured in two key aspects: the first, on an enlargement of medical and administrative staff working in Miguel Bombarda's Hospital, approved on $16^{\text {th }}$ November 1911, and maintained in the following years. The second issue consisted in a complete subordination of private entities to state's purposes and, more relevant, scientific administration. Controversial decision, the option for a public and direct supervision upon all charity and medical agents operating in Portugal contributed highly to negative reception of republican institutions in rural areas, close to Catholicism and its representatives.

The presence of Saint John of God, associated to psychiatric assistance in Portugal, turned to be a huge question for republican institutions since the principles adopted by Provisional Government, according to political programme approved by Republican Party in 1891, were consistent with a clear separation between State and its functions, and the all churches, especially the Catholic. Consequently, on $20^{\text {th }}$ 
April 1911, by initiative of Justice Ministry, the republican executive announced a law, reducing greatly the margins of performance admitted to Catholic Church. Before, immediately after the republican revolution, the new institutions applied liberal laws, expelling all religious orders from national territories. Saint John of God' order was an exception to this rule, being allowed to stay in Portugal and to maintain its activities and both houses, although strongly conditioned. The scientific administration had to be appointed by the ministry of Interior.

Similar discomfort was felt in Porto: the Count Ferreira's Hospital, integrated in public network since the late $19^{\text {th }}$ century, was a private institution, managed by charity organization - a Santa Casa da Misericórdia - also responsible for funding, strictly private. By appointing the scientific dean to the institution, Portuguese Republic seemed to neglect regional powers, a sensitive matter in the new institutional environment. Thus, Almeida, the author's 1911 decree, tried to insert a strict change, allowing Porto's Misericórdia to recovery full control of its hospital, on 1912. The debate took place in parliament during this and the following year, causing huge polemic between members of 1910 executive, regarding the opportunity and legality of a measure conceived to benefit a single entity [26].

By 1913, Portuguese financial instability and foreign pressures regarding the external public debt forced a general tax reforms and new perspectives on State's intervention in social and health areas. The assumption of these priorities, particularly relevant to republican institutions facing a harsh diplomatic environment in Europe, as Great Britain and German Empire considered, once again, Portuguese colonies as a legitimate and efficient mean to overcome tensions between the two powers; or, on the other hand, as Spain announced publicly the intention to neutralize any threats to Spanish political regime and institutions, providing an additional information to Great Britain on its purposes of establishing Iberian peninsula by taking over Portuguese chaotic republic if needed.

Answering to external pressures, republican democratic executive redefined State's most urgent necessities on public health, favouring a centralized model, not so different from monarchical's options. As so, the $28^{\text {th }}$ June 1914 proposal on health national system organization predicted a direct cooperation between all public hospitals in Lisbon, considering also the advantage of delaying the full implementation of 1911 decree and regulations in order to contain financial costs and achieve a positive budgetary balance.

\section{Conclusion}

The absence of a national health system, particularly the lack of specialized care devoted to mental illness, assumed an important role in Portuguese republican propaganda since the last decade of $19^{\text {th }}$ century until 1910. Undoubtedly, for Portuguese republicans, prejudices and inhuman conditions in which psychiatric patients lived in Portugal were a full demonstration of monarchical's incapacities to achieve moder- 
nity. Instead adopting European patterns, considering English, French and Germans options, Portuguese State neglected its sovereign functions by not showing interest in identifying the precise number of ill persons, the causes of mental disorder or the right treatments to promote a real recovery. On the other hand, political debate surrounding monarchy and its representatives was also influenced by the subject once the failure of Portuguese political institutions found an explanation in royal family degeneration, in both physics and psychiatrics senses, a premise characterized by the large popular impact between 1908 and 1910.

After republic's implementation, on October 1910, new political institutions promoted an approach to psychiatric disease through different levels as the reform of university and the introduction of psychiatric speciality in every new teaching entity. Also, that was acheived by the creation of assistance public system, conceived to fight poverty, which was considered as the crucial environment to the development of mental disorders. At last, through the promotion of a specific regulation regarding the assistance offered to mental illness patients. Nevertheless, although republican regime revealed the ability to conceive a medical structure destined to provide the proper treatments according to patients' needs, the state's financial weakness and external pressures established other priorities. By the beginning of Great War, the expectations nourished by Portuguese Republic in 1911 were overcome by the issue of war.

\section{Rezime}

Nedostatak nacionalnog zdravstvenog sistema, pogotovu posebne nege za pacijente koji su patili od mentalnih bolesti, zauzimao je važno mesto u propagandnom narativu portugalskih Republikanaca između poslednje decenije XIX veka i prve dekade XX stoleća. Za njih su nehumani uslovi i predrasude kojima su psihijatrijski pacijenti u Portugalu bili izloženi predstavljali ključni dokaz nemogućnosti monarhije da dostigne modernost. Umesto usvajanja evropskih obrazaca, portugalska država je zapostavila svoje suverene funkcije time što nije pokazala interesovanje da utvrdi tačan broj bolesnih osoba, uzroke mentalnih poremećaja i pronađe načine da podstakne istinski oporavak. S druge strane, političke rasprave u vezi sa monarhijom i njenim predstavnicima takođe su bile pod uticajem ovog narativa, pogotovo nakon što je kao razlog neuspeha portugalskih institucija označena degeneracija kraljevske porodice, i u fizičkom i u psihičkom smislu, što je bila veoma uticajna premisa između 1908. i 1910.

Nakon uspostavljanja Republike u oktobru 1910, nove političke institucije su promovisale pristup mentalnim bolestima na različitim nivoima, poput reforme univerziteta i uvođenja psihijatrijske specijalizacije u svakoj novoj obrazovnoj instituciji. Takođe, to je postignuto stvaranjem javnog sistema namenjenog borbi protiv siromaštva, koje je smatrano ključnim uzrokom razvoja mentalnih oboljenja. Na kraju, od uticaja je bilo i promovisanje posebne regulacije u vezi sa pomoći koja se nudila 
mentalno obolelim pacijentima. U svakom slučaju, iako se republikanski režim pokazao sposobnim da osmisli zdravstveni sistem namenjen da pruži lečenje u skladu sa potrebama pacijenata, finansijska slabost države i spoljni pritisci su nametnuli druge prioritete. Izbijanje Prvog svetskog rata je u potpunosti pomračilo očekivanja portugalske Republike na ovom planu.

\section{References:}

1. Sena AMD. Os alienados em Portugal. I História e Estatística [Those alienated in Portugal. I History and Statistics]. Professor Substituto na Faculdade de Medicina da Universidade de Coimbra, em comissão na direcção do Hospital de Alienados do Conde de Ferreira; II Hospital do Conde de Ferreira. Lisbon: Medicina Contemporânea; 1884.

2. Pinel P. Institutions de Médicine-Pratique traduits sur la quatrième et dernière édition de louvrage anglais. Paris: imp. De Cl. Simon; 1785.

3. Pinel P. Nosographie philosophique ou la méthode de l'analyse appliquée à la Médicine. Paris: Chez Ricard, Caille et Ravier; 1789.

4. Pinel P. Traité Médico-Philosophique sur l’aliénation mentale, $2^{\mathrm{e}}$ édition. Paris: imp. de Feugueray; 1809.

5. Esquirol JED. Delle Alienazione Mentale ou Della Pazzia in genere e in ispecie. I-II. Milano: Ci tipi di Felice Rusconi; 1827.

6. Notes sur l'état des Aliénés en Portugal, Madère et Tenerife. Ann Med Psychol. 1844;44(III):368.

7. Miguel EE. Figuras Historicas de la Psiquiatría Alemana [Historical Figures of German Psychiatry]. Revista GPU. 2012;8(3):351-8.

8. Estatística de Portugal. População [Portugal Statistics. Population]. 1878, vol. I. Lisbon: Imprensa Nacional; 1881. p. XXVII.

9. População do Reino de Portugal no $1^{\circ}$ de Dezembro de 1890 [Population of the Kingdom of Portugal on December $1^{\text {st }}$, 1890]. Lisbon: Imprensa Nacional; 1906. pp. 176-7.

10. A Medicina Contemporânea. 1889 July;8(29):217-9.

11. Diário da Câmara dos Deputados [Diary of the Chamber of Deputies]. Lisbon. 1908 26 ${ }^{\text {th }}$ May $17 ; 8$.

12. Catroga F. O Republicanismo em Portugal: da formação ao 5 de Outubro de 1910 [The Republicanism in Portugal: from the formation to $5^{\text {th }}$ of October 1910]. I. Coimbra: Faculdade de Letras; 1991.

13. Ventura A. Anarquistas, Republicanos e Socialistas. As Convergências Possíveis (18921910) [Anarchists, Republicans and Socialists. The Possible Convergences (1892-1910)]. Lisbon: Cosmos; 2000.

14. Araújo PADSPL. Miguel Bombarda: Ciência, Política e Assistência Mental [Miguel Bombarda: Science, Politics and Mental Health] [master's thesis]. [Braga (PT)]; Universidade do Minho; 2003.

15. A Medicina Contemporânea. 1891 March;9(12):91-3.

16. A Medicina Contemporânea. 1894 June/July;12(23-29):222-4; 271.

17. A Medicina Contemporânea. 1898 September;14(36): 289. 
18. O Paiz. 1895 November 29; n², p. 3.

19. Diário da Câmara dos Deputados [Diary of the Chamber of Deputies]. 1909 April 24; 4-17.

20. Diário da Câmara dos Deputados [Diary of the Chamber of Deputies]. 1910 June 28; 9.

21. Torgal LR. António José de Almeida e a República: discurso de uma vida ou vida de um discurso [António José de Almeida and the Republic: discourse of a life or life of a discourse]. Lisboa: Temas e Debates; 2005.

22. Diário da Câmara dos Deputados [Diary of the Chamber of Deputies]. 1907 February $31 ; 3$.

23. Diário da Câmara dos Deputados [Diary of the Chamber of Deputies]. 1907 April 52; $10-17$.

24. Diário da Câmara dos Deputados [Diary of the Chamber of Deputies]. 1908 August 21.

25. Mello AD. A Imbelicidade e a degenerescência nas Famílias Reais. A Hereditariedade, as suas taras físicas, os estigmas intelectuais de degenerescência, as perturbações nutritivas, a educação, o problema sexual, a loucura mística [Imbelicity and degeneracy in the Royal Families. Heredity, their physical defects, the intellectual stigmas of degeneracy, nutritional disorders, education, the sexual problem, mystical madness]. Lisbon: Livraria Central de Gomes de Carvalho; 1908.

26. Diário da Câmara dos Deputados [Diary of the Chamber of Deputies]. 1913 June 130; $10-15$.

Submitted: 20. 11. 2017.

Reviewed: 29. 11. 2017.

Accepted: 04. 12. 2017. 